\title{
VOLUNTARY INSTRUMENTS OF ENVIRONMENTAL CARE AS A GLOBAL TREND - EXAMPLE OF THE SITAUTION IN THE CZECH REPUBLIC
}

\begin{abstract}
The presented paper discusses the importance of voluntary environmental activities to business activity. In recent decades, a number of trends have been underway that have increased the importance of a friendly approach to the environment for the successful functioning of enterprises. A certain level of environmental care is given by the legislative requirements of the country. At the same time, enterprises can develop activities beyond those mandatory obligations. The aim of the presented article is to provide a list of the basic voluntary instruments that businesses use to take a friendly approach to the environment and, using selected instruments, describe their use in the Czech Republic. A further aim is to briefly map the opinions of the inhabitants of the Czech Republic concerning the status and protection of the environment in the Czech Republic. Businesses can use several voluntary environmental tools. EMAS and ecolabelling are considered the main voluntary environmental instruments. The potential benefits of both tools include possible cost savings as well as a possible increase in revenues. In the Czech Republic, both voluntary instruments mentioned above are used. Research focused on the impact of voluntary environmental tools on business performance has shown that their use mostly increases environmental performance. Greater economic performance is not always achieved. A survey conducted among the citizens of the Czech Republic indicated that they are quite satisfied with the state of the environment. Furthermore, it is possible to identify potential demand for environmentally friendly products.
\end{abstract}

Keywords: environmental strategy; ecolabelling; EMAS; voluntary instruments.

\section{INTRODUCTION}

Global trends and changes in the business environment are very important considerations for business strategy ${ }^{2}$. Reflections on these issues can bring enterprises various benefits, including the opportunity to obtain a competitive advantage.

There are many global trends in the area of the environment. For example, Done ${ }^{3}$ specifies twelve trends: repercussions of the crisis, geopolitical power shifts, technological challenges, climate change, water and food, education, demographic changes, war, terrorism and social unrest, energy, ecosystems and biodiversity, health, and natural disasters. At least half of these trends (climate change, water and food, demographic

\footnotetext{
${ }^{1}$ Ing. et Ing. Josef Krause, Ph.D. Department of Strategy, Faculty of Business Administration, University of Economics, Prague, W. Churchill Sq. 1938/4, 13067 Prague 3, Czech Republic.

${ }^{2}$ G. Johnson, K. Scholes, R. Whittington, Exploring corporate strategy: Text and cases, $8^{\text {th }}$ ed., Prentice Hall, Harlow 2008; R.M. Grant, Contemporary strategy analysis: Text and cases, $9^{\text {th }}$ ed., Chicester: John Wiley \& Sons Inc. 2016. M.E. Porter, Competitive strategy: Techniques for analyzing industries and competitors, $8^{\text {th }}$ ed., Harlow: Prentice Hall, Harlow 2004; B. de Wit, R. Meyer, Strategy synthesis: Managing strategy paradoxes to create competitive advantage, $4^{\text {th }}$ ed., Andover: Cengage Learning 2014.

${ }^{3}$ A. Done, Global trends: Facing up to a changing world, $1^{\text {st }}$ ed., Palgrave Macmillan, Basingstoke 2012.
} 
changes, energy, ecosystems and biodiversity, natural disasters) can be considered questions of sustainability. The importance of trends in the area of sustainability has also been confirmed by other authors. Examples of functional trends are "environment and energy", according to Dabelko ${ }^{4}$ and "economics and energy", according to Gates" Climate change is mentioned as one of the most important trends by Soucek ${ }^{6}$.

Care for the environment is also a part of the concept of corporate social responsibility. It is traditionally based on three pillars: economic, social, and environmental. The environmental pillar, according to Srpová et al. (2012), includes the following elements: protection of natural resources, reduction of negative impacts on the environment, recycling, use of environmentally friendly products, use of alternative energy sources, and compliance with standards ISO 140 and EMAS.

The aim of the presented article is to provide a list of the basic voluntary instruments that businesses use to take a friendly approach to the environment and, using selected instruments, describe their use in the Czech Republic. A further aim is to briefly map the opinions of the inhabitants of the Czech Republic on the status and protection of the environment in the Czech Republic.

\section{POSITIVE IMPACT OF ENVRIONMENTAL PERFORMANCE}

Many authors argue that environmental issues are important ingredients of a business strategy. Russo et al. ${ }^{7}$ analysed 243 such issues and confirmed that economic performance and environmental performance are positively linked. They also discovered a positive relationship between this link and the growth of industry.

Young et al. $^{8}$ state that sustainability can increase profitability and competitiveness. These authors specify ten reasons why the question of sustainability is important for companies. These reasons are volatile energy prices, increases in the cost of raw materials, increases in waste and disposal costs, changes in waste legislation, strengthening of environmental laws, changes in customer demands and expectations, competitive advantages, transparency issues, acquisition, retention, and motivation of astute employees, and the cost of procrastination.

In addition, Hitchcock et al. ${ }^{9}$ cite many potential benefits of pursuing sustainability. These benefits are reducing energy, waste and costs, differentiating companies, meeting future regulations, developing new product or processes innovations, opening new markets, attracting the best employees, improving the image among shareholders, legal risk, reducing insurance costs, higher quality of life.

\footnotetext{
${ }^{4}$ G.D. Dabelko, Environment and energy. In ed. Arnas, N.: Fighting chance: Global trends and shocks in the national security environment, $1^{\text {st }}$ ed., Center for Technology and National Security Policy, Washington 2009.

${ }^{5}$ D.F. Gates, Economics and energy. In. ed. Arnas, N.: Fighting chance: Global trends and shocks in the national security environment, $1^{\text {st }}$ ed., Center for Technology and National Security Polic, Washington 2012.

${ }^{6}$ Z. Soucek, Strategie úspěšného podniku: symbióza kreativity a dsicipliny, $1^{\text {st }}$ ed., C.H. Beck, Prague 2015.

${ }^{7}$ M.V. Russo, P.A. Fouts, A resource-based perspective on corporate environmental performance and profitability, "Academy of Management Journal" 1997/3, p. 534-559.

${ }^{8}$ S.T. Young, K.K. Dhanda, Sustainability: Essentials for business. Sage, Los Angeles 2013, 416 pp.

${ }^{9}$ D. Hitchcock, M. Willard, Marsha. The business guide to sustainability: Practical strategies and tools for organizations, $2^{\text {nd }}$ ed., London 2009.
} 
Li et al. ${ }^{10}$ examined 256 Chinese-based high-tech firms. The authors confirmed that green product design and green supply-chain processes play an important role in the environmental and financial performance of the companies. Wu et al. ${ }^{11}$ confirmed that green marketing strategies have a positive impact on the business performance of organic farms in Taiwan.

Research by Eiadat et al. ${ }^{12}$ examined an environmental innovation strategy and its link to business performance. The research was based on Jordanian firms in the chemical industry. This research also found an association between an environmental innovation strategy and better business performance.

UEAPME $^{13}$ mentions environmental management systems (EMAS) and ecolabelling (EUAPME, 2016) as voluntary environmental instruments. According to Hadrabova ${ }^{14}$, environmental management systems involve the EMAS and ISO 14000 standards. The European Commission further adds green procurement ${ }^{15}$.

\subsection{Consumer views on environmental protection in the Czech Republic ${ }^{16}$}

$68 \%$ of the population are satisfied (very satisfied or rather satisfied) with the state of the environment in the Czech Republic. Certain differences can be found in different areas of the environment. Most of the population is satisfied with the quality of drinking water $(84 \%)$, availability of wilderness areas $(83 \%)$, purity of the surrounding countryside $(77 \%)$, clean air $(64 \%)$, noise level $(61 \%)$, purity of surface waters $(59 \%)$, and traffic density $(41 \%)$. Satisfaction with various aspects of the environment is higher (except for satisfaction with the purity of drinking water) in small villages in comparison with large cities. It is interesting to note the answer to the question of whether respondents are interested in information concerning the environment in the Czech Republic. 57\% of the respondents answered that they are interested in such information. At the same time, only

${ }^{10}$ S.R. Li, V. Jayaraman, A. Paulraj, K.C. Shang, Proactive environmental strategies and performance: Role of green supply chain processes and green product design in the Chinese high-tech industry, "International Journal of Production Research" 2016, 54/7.

${ }^{11}$ S.I. Wu, S.R. Lin, The effect of a green marketing strategy on business performance: A study of organic farms in Taiwan. Total Quality Management and Business Excellence" 2016. 27/2, pp. 141-156.

${ }^{12}$ Y. Eiadat, A. Kelly, F. Roche, H. Eyadat, Green and competitive? An empirical test of the mediating role of environmental innovation strategy. "Journal of World Business" 2008, 43/2, pp. 131-145.

${ }^{13}$ The European Association of Craft, Small and Medium-Sized Enterprises

${ }^{14}$ A. Hadrabova, Environmentální aspekty podnikání. Oeconomica, Prague 2010

15 EC, EU voluntary environmental protection instruments. European Commission. Available on-line: http://europa.eu/rapid/press-release_MEMO-06-6_en.htm; 12 August 2016.

${ }^{16}$ The research cited in this part of the article was carried out by the Public Opinion Research Center (part of the Institute of Sociology of the Czech Academy of Sciences). The research is based on quota sampling. Quotas are according to region (NUTS 3), size of residence, gender, age and education. The representativeness is related to residents of the Czech Republic who are 15 years of age or older. The size of the sample was 1015 respondents. The method used for the research was an interview with the respondents according to a standardized questionnaire (SOU AV CR. Hodnocení stavu životního prostředí - květen 2016. Centrum pro výzkum veřejného mínění. Sociologický ústav AVČR, v.v.i. Available online: http://cvvm.soc.cas.cz/en/ media/com_form2content/documents/c1/a7335/f3/oe160615.pdf; 1 October 2016; SOU AV CR, Hodnocení ochrany životního prostředí - květen 2016. Centrum pro výzkum veřejného mínění. Sociologický ústav AVČR, v.v.i. Available online: http://cvvm.soc.cas.cz/media/com_form2content/ documents/c1/a7568/f3/oe 160613.pdf; 1 October 2016; SOU AV CR, Postoje k ochraně životního prostředí a jejímu financování květen 2016. Centrum pro výzkum veřejného mínění. Sociologický ústav AVČR, v.v.i. Available online: http://cvvm.soc.cas.cz/media/com_form2content/documents/c1/a7570/f3/oe160621.pdf; 1 October 2016.). 
$43 \%$ of the respondents answered that there is enough information about the environment in the Czech Republic ${ }^{17}$.

According to the opinion of $59 \%$ of the respondents, the Czech Republic cares about the environment appropriately, while $35 \%$ of the respondents feel this is done poorly. In terms of evaluating the environmental protection activities of various institutions, municipal authorities were evaluated as the best. $64 \%$ of the respondents view their work positively. $55 \%$ of the respondents mentioned the good work of environmental organizations, $47 \%$ mentioned the Ministry of the Environment, $41 \%$ the regional offices, $36 \%$ the government, $32 \%$ the European Union, and only $23 \%$ of the respondents mentioned the parliament. In terms of assessing the situation in individual areas of environmental performance, according to the respondents the situation is good in the economy of consumption of raw materials and energy by citizens (44\%), impact of agricultural activities on the environment (42\%), renewable energy (38\%), citizen behaviour toward the environment (34\%), the rigor of laws on environmental protection $(30 \%)$, economics of the consumption of raw materials and energy in our production (30\%), impact of logging on the environment (26\%), being friendly to natural areas during construction (22\%), behaviour of enterprises toward the environment (21\%), prosecution of those who damage the environment (19\%), impact of mineral extraction on the environment $(17 \%)$, and impact of road transport on the environment $(16 \%)^{18}$.

According to consumer research conducted in the Czech Republic, the prevailing view is that it is right to do something for the environment, even if it costs more money or demands more time. $82 \%$ of the respondents strongly agreed or agreed with this statement. At the same time, another survey suggests that consumers are not as optimistic about their ability as individuals to affect things in the environment. $51 \%$ of the respondents said they strongly agree or agree with the assertion that it is difficult for them to do something more for the environment as individuals. And $35 \%$ of the respondents agreed with the statement that their activity in the environmental field will not be relevant unless other people are active as well. At the same time, $38 \%$ of the respondents agreed (strongly agreed or agreed) with the statement that there are more important things in life than concern for the environment. In the field of environmental protection, $74 \%$ of the respondents agreed with the statement that the problem of environmental pollution must be resolved without spending money. Only $31 \%$ of the respondents would be willing to give part of their revenue for environmental protection, and $27 \%$ of the respondents approved of raising taxes if these resources were to be spent on environmental protection ${ }^{19}$.

\subsection{Ecolabelling}

Along with new trends (globalization, climate change) also come new needs of customers. Ecolabelling is one of the ways to satisfy these needs. The main arguments and benefits of the voluntary tools for customers are: strict criteria for granting certification by independent bodies, products which have less impact on the environment, products which

\footnotetext{
${ }^{17}$ SOU AV CR, Hodnocení stavu životního prostředí - květen 2016. Centrum pro výzkum veřejného mínění. Sociologický ústav AVČR, v.v.i. Available on-line: http://cvvm.soc.cas.cz/en/media/com_form2content/ documents/ c1/a7335/f3/oe160615.pdf; 1 October 2016.

${ }^{18}$ SOU AV CR, Hodnocení ochrany životního prostředí - květen 2016.

${ }^{19}$ EC, Search engine for EMAS registrations. European Commission. Available on-line: http://ec.europa.eu/environment/emas/register/search/search.do; 5 July 2016
} 
are better for consumer health, contribution to sustainable development, and a certification backed by the European Commission ${ }^{20}$.

The main objectives of the criteria for awarding ecolabels are formulated as follows, according to $\mathrm{EC}^{21}$ : "The EU Ecolabel seeks to minimize the various environmental impacts at each stage of a product's life. The criteria are set at levels that promote products which have a lower overall environmental impact".

In the Czech Republic, products holding the designation "environmentally friendly product" are classified into the following areas: dry cleaning, household and office, house, garden, workshop, service, construction and reconstruction, heating, and other. 60 manufacturers hold this designation. The structure of licensing by individual groups is indicated in the table.

Chart 1. Structure of product groups holding an ecolabel in the Czech Republic

\begin{tabular}{|l|l|}
\hline Absorbents & $1.06 \%$ \\
\hline Wood-burning boilers & $1.06 \%$ \\
\hline Metal furniture & $1.06 \%$ \\
\hline Lubricants & $1.06 \%$ \\
\hline Mulch material from recycled paper & $1.06 \%$ \\
\hline Absorbents & $1.06 \%$ \\
\hline Spreading materials & $1.06 \%$ \\
\hline Hard floor coverings & $1.06 \%$ \\
\hline Textile products & $2.13 \%$ \\
\hline Adhesives and sealants, water-soluble & $2.13 \%$ \\
\hline Printed paper & $3.19 \%$ \\
\hline Products from molded pulp & $1.06 \%$ \\
\hline Detergents & $3.19 \%$ \\
\hline Products from a "tissue" paper & $3.19 \%$ \\
\hline Gas boilers & $4.26 \%$ \\
\hline $\begin{array}{l}\text { Cardboard, paperboard and articles } \\
\text { thereof }\end{array}$ & $6.38 \%$ \\
\hline Accommodation services for tourists & $8.51 \%$ \\
\hline Pipes of polyolefin & $10.64 \%$ \\
\hline Paints containing water & $20.21 \%$ \\
\hline Furniture & $27.66 \%$ \\
\hline Total & $100.00 \%$ \\
\hline
\end{tabular}

Source: Cenia. Produkty s ekoznačkou Ekologicky šetrný výrobek/služba a Ekoznačkou EU udělenou $v \breve{C} R$. The Czech environmental information agency. Available on-line: http://www1.cenia.cz/www/ekoznaceni/seznam-esv; 6 July 2016.

These figures show that more than half $(57 \%)$ of all licenses are awarded in three product groups: furniture, paints containing water, and pipes of polyolefin. The groups "accommodation services" and "cardboard, paperboard and articles thereof" have at least a $5 \%$ representation (but less than $10 \%$ ). Other groups have less than $5 \%$.

${ }^{20} \mathrm{EC}$, Marketing guide for EU Ecolabel companies: How to make the EU flower visible in your marketing. European Commission. 2007. Available on-line: http://ec.europa.eu/environment/ecolabel/documents/ marketing_guide_en.pdf; 20 August 2016.

21 EC, EU Ecolabel paints and varnishes user manual. European Commission. Available on-line: http://ec.europa.eu/environment/ecolabel/documents/User_Manual_paints_varnishes.pdf; 1 August 2016. 


\section{Research on the benefits of ecolabelling}

Karlsson et al. ${ }^{22}$ examined the impact of the ecolabelling of tourism services and the demand for them. The authors observed that ecolabelling is not very important for the wider tourism segment. However, the research confirmed the existence of a niche market that is interested in providers with this type of certification. Delmas et al. ${ }^{23}$ examined the impact of ecolabelling and the certification of environmental practices. The authors observed that ecocertification brought a premium price, but an ecolabel did not bring this premium price.

\subsection{EMAS} $\operatorname{are}^{24}:$

EMAS is an environmental management system. The potential benefits of this system

Reduced operating costs. EMAS can help to reduce the cost of raw materials, energy, and charges for environmental pollution;

- Reduced risk of accidents;

- Reduced cost of fines for environmental pollution;

- Improvement of access to licenses, certificates, etc.;

- Better access to capital (grants, loans, public procurement);

- Improved business organization, clarified organizational structure, clearly defined business plan.

In addition, a document from the European Commission specifies similar benefits of EMAS: resource efficiency, climate protection, corporate social responsibility, legal compliance, supply chain management and green public procurement, credible information, performance measurement, employee engagement, and stakeholder involvement ${ }^{25}$.

In recent years, the number of certified operators has been around 25 . The maximum number of certified organizations was achieved in 2009. It is expected that the decline after 2009 was associated with the financial crisis and the financial demands of this certification.

Chart 2. Number of EMAS holders in the Czech Republic

\begin{tabular}{|l|r|r|r|r|r|r|r|r|}
\hline geoltime & 2008 & 2009 & 2010 & 2011 & 2012 & 2013 & 2014 & 2015 \\
\hline Czech Republic & 28 & 34 & 26 & 25 & 24 & 24 & 25 & 24 \\
\hline
\end{tabular}

Source: Eurostat, Organisations and sites with eco-management and audit scheme (EMAS) registration. Available online:

http://ec.europa.eu/eurostat/tgm/table.do?tab=table\&init=1\&plugin=1\&language=en \& pcode $=$ tsdpc $410 ; 3$ August 2016.

\footnotetext{
${ }^{22}$ L. Karlsson, S. Dolnicar, Does eco-certification sell tourism services? Evidence from a quasi-experimental observational study in Iceland, "Journal of Sustainable Tourism" 2015, 24/5.

${ }^{23}$ M.A. Delmas, L.E. Grant, Eco-labeling strategies and price-premium: The wine industry puzzle, "Business and Society" 2010, 53/1.

${ }^{24}$ MECR, Aktualizovaný program EMAS (Základni dokumenty). Ministry of Environment of the Czech Republic, 2002.

${ }^{25}$ EC (2012). $3 \times 3$ Good Reasons for EMAS: Improve your environmental performance with the premium standard in environmental management. European Commission. Luxembourg: Publications Office of the European Union. Available on-line: http://ec.europa.eu/environment/emas/pdf/other/Brochure_3x3_Good_reasons_ for_EMAS.pdf; (dostęp: 1.08.2016 r.).
} 
The structure of enterprises by sector having an EMAS certification in the Czech Republic (EMAS register of the European Commission, $\mathrm{EC}^{26}$ ):

- Manufacturing industry $-40 \%$.

- Production and distribution of electricity, gas, steam and air conditioning $-10 \%$.

- Construction $-25 \%$.

- Public administration and defence; compulsory social security $-15 \%$.

- Health and social care $-5 \%$.

\section{Research on EMAS benefits}

Merli et al. ${ }^{27}$ examined the benefits of EMAS holders in Italy. The authors examined the strategic, environmental, and economic benefits of certification. The most important strategic benefits are improvement of legislative compliance and improvement of image. The least important factors are improvement in relations with staff and improvement of access to public funds and tenders. The most important environmental benefits are a reduction in waste generation and in the use of resources, raw materials, and energy. The least important benefits of an EMAS certification are reductions in the use of soil, in soil contamination, and in effects on biodiversity. The most important economic benefits are energy savings and savings in the use of raw materials. The least important economic benefits are savings on insurance premiums and an increase in turnover. The research was further aimed at detecting difficulties with the EMAS certification. The most important difficulties are lack of staff time and difficulties related to the initial environmental review.

Martin-Pena et al. ${ }^{28}$ also examined the benefits and difficulties associated with EMAS certification. The research was focused on the automotive industry in Spain. The main benefits detected were improvements in market position, environmental performance, relations with stakeholders, and access to environmentally friendly technologies. The most important difficulties were connected with the organisational structure, staff, and environmental information.

Iraldo et al. ${ }^{29}$ examined the impact of EMAS certification on environmental and competitive performance. The impact on environmental performance was confirmed. The effects on competitive performance were not strongly confirmed.

\section{CONCLUSION}

Voluntary business instruments in environmental care can bring enterprises a number of benefits. The main benefits include a reduction in operating costs and risk of accidents, lower costs associated with environmental pollution, improvement of the transparency of processes within the organization, and greater attractiveness to customers and other interest groups. According to numerous studies dealing with an evaluation of the impact

26 EC (2016). Search engine for EMAS registrations. European Commission. Available on-line: http://ec.europa.eu/environment/emas/register/search/search.do; 5 July 2016.

${ }^{27}$ R. Merli, M. Preziosi, Ch. Ippolito, Promoting sustainability through EMS application: A survey examining the critical factors about EMAS registration in Italian organizations, "Sustainability" 2016. 8/3

${ }^{28}$ M.L. Martin-Pena, E. Diaz-Garrido, J.M. Sanchez-Lopez, Analysis of benefits and difficulties associated with firms' Environmental Management Systems: The case of the Spanish automotive industry, "Journal of Cleaner Production" 2014, 70.

${ }^{29}$ F. Iraldo, F. Testa, Is an environmental management system able to influence environmental and competitive performance? The case of the eco-management and audit scheme (EMAS) in the European Union, 2009, 17/16. 
of selected tools on enterprises, it is evident that these benefits are not always realized in practice. Further research should therefore focus on the conditions under which businesses can reap all the potential benefits of these tools. The inhabitants of the Czech Republic are rather satisfied with the environment, and they agree that it should be protected. This attitude can be identified as an opportunity for firms. Ecolabelling and the EMAS certification are used in the Czech Republic, but their use is not widespread.

Acknowledgements

Supported by financial aid from the Internal Grant Agency at the University of Economics, Prague (project IP 3040 26). This concept is aimed at the concept of sustainable corporate responsibility. This concept focuses on the aspect of long-term sustainability. This means not only on three pillars (social, economic, environmental) but also on a time dimension of responsibility. The project explores the effects of CSR on economic indicators and the time dimension of the connections between CSR activities and economic effects in the conditions of the Czech Republic. The presented review in this article serves as an introductory phase for the preparation of a questionnaire survey between businesses investigating given areas.

\section{REFERENCES}

[1] Cenia, Produkty s ekoznačkou Ekologicky šetrný výrobek/služba a Ekoznačkou EU udělenou v $\check{C} R$. The Czech environmental information agency. Available online: http://www1.cenia.cz/www/ekoznaceni/seznam-esv; 6 July 2016.

[2] Dabelko G.D., Environment and energy. In ed. Arnas, N.: Fighting chance: Global trends and shocks in the national security environment, $1^{\text {st }}$ ed., Center for Technology and National Security Policy, Washington 2012.

[3] Delmas, M.A., Grant, L.E., Eco-labeling strategies and price-premium: The wine industry puzzle, "Business and Society" 2010, 53/1.

[4] Done A., Global trends: Facing up to a changing world, $1^{\text {st }}$ ed., Palgrave Macmillan, Basingstoke 2012.

[5] EC, Marketing guide for EU Ecolabel companies: How to make the EU flower visible in your marketing. European Commission. 2007. Available online: http://ec.europa.eu/environment/ ecolabel/documents/marketing_guide_en.pdf; 20 August 2016.

[6] EC, $3 \times 3$ Good Reasons for EMAS: Improve your environmental performance with the premium standard in environmental management. European Commission 2012. Luxembourg: Publications Office of the European Union. Available online: http://ec.europa.eu/environment/ emas/pdf/other/Brochure_3x3_Good_reasons_for_EMAS.pdf; 1.8.2016

[7] EC, EU voluntary environmental protection instruments. European Commission. Available online: http://europa.eu/rapid/press-release_MEMO-06-6_en.htm; 12 August 2016

[8] EC,. EU Ecolabel paints and varnishes user manual. European Commission. Available online: http://ec.europa.eu/environment/ecolabel/documents/User_Manual_paints_ varnishes.pdf; 1 August 2016.

[9] EC,. Search engine for EMAS registrations. European Commission. Available online: http://ec.europa.eu/environment/emas/register/search/search.do; 5 July 2016.

[10] Eiadat Y., Kelly A., Roche F., Eyadat H., Green and competitive? An empirical test of the mediating role of environmental innovation strategy, "Journal of World Business" 2008, 43/2, pp. 131-145.

[11] Gates D.F., Economics and energy. In. ed. Arnas, N.: Fighting chance: Global trends and shocks in the national security environment, $1^{\text {st }}$ ed., Center for Technology and National Security Polic, Washington 2012.

[12] Hadrabova A., Environmentální aspekty podnikání. Prague: Oeconomica, Prague 2010. 
[13] Hitchcock D., Willard M., Marsha. The business guide to sustainability: Practical strategies and tools for organizations, $2^{\text {nd }}$ ed., Earthscan, London 2009.

[14] Iraldo F., Testa F., Is an environmental management system able to influence environmental and competitive performance? The case of the eco-management and audit scheme (EMAS) in the European Union, 2009,17/16.

[15] Johnson G., Scholes K., Whittington R., Exploring corporate strategy: Text and cases, $8^{\text {th }}$ ed., Prentice Hall, Harlow 2008.

[16] Karlsson L., Dolnicar S., Does eco-certification sell tourism services? Evidence from a quasiexperimental observational study in Iceland, "Journal of Sustainable Tourism" 2015, 24/5.

[17] Li S.R., Jayaraman V., Paulraj A., Shang K.C., Proactive environmental strategies and performance: Role of green supply chain processes and green product design in the Chinese high-tech industry. International Journal of Production Research" 2016, 54/7.

[18] Martin-Pena M.L., Diaz-Garrido E., Sanchez-Lopez J.M., Analysis of benefits and difficulties associated with firms' Environmental Management Systems: The case of the Spanish automotive industry, "Journal of Cleaner Production" 2014, 70.

[19] MECR Aktualizovaný program EMAS (Základni dokumenty). Ministry of Environment of the Czech Republic 2002.

[20] Merli, R., Preziosi, M., Ippolito, Ch. (2016). Promoting sustainability through EMS application: A survey examining the critical factors about EMAS registration in Italian organizations. Sustainability. $8 / 3$

[21] Porter M.E., Competitive strategy: Techniques for analyzing industries and competitors, $8^{\text {th }}$ ed., Prentice Hall, Harlow 2004.

[22] Russo M.V., Fouts P.A., A resource-based perspective on corporate environmental performance and profitability. Academy of Management Journal” 1997/3, p. 534-559.

[23] Soucek Z., Strategie úspěšného podniku: symbióza kreativity a dsicipliny, $1^{\text {st }}$ ed., Prague: C.H. Beck, Prague 2015.

[24] SOU AV CR, Hodnocení stavu životního prostředí - květen 2016. Centrum pro výzkum veřejného mínění. Sociologický ústav AVC̆R, v.v.i. Available online: http://cvvm.soc.cas .cz/en/media/com_form2content/documents/c1/a7335/f3/oe160615.pdf; 1 October 2016.

[25] SOU AV CR,. Hodnoceni ochrany životniho prostředi - květen 2016. Centrum pro výzkum veřejného mínění. Sociologický ústav AVČR, v.v.i. Available online: http://cvvm.soc.cas.cz /media/com_form2content/documents/c1/a7568/f3/oe160613.pdf; 1 October 2016.

[26] SOU AV CR, Postoje k ochraně životního prostředí a jejímu financování - květen 2016. Centrum pro výzkum veřejného mínění. Sociologický ústav AVČR, v.v.i. Available online: http://cvvm.soc.cas.cz/media/com_form2content/documents/c1/a7570/f3/oe160621.pdf; October 2016.

[27] Young S., Dhanda K.K.,. Sustainability: Essentials for business. Sage, Los Angeles 2013, 416 pp.

[28] Wu S.I., Lin S.R.,. The effect of a green marketing strategy on business performance: A study of organic farms in Taiwan, "Total Quality Management and Business Excellence" 2016, 27/2, pp. 141-156.

\section{DOBROWOLNE INSTRUMENTY OCHRONY ŚRODOWISKA NATURALNEGO JAKO JEDEN Z TRENDÓW GLOBALNYCH - PRZYKLAD SYTUACJI W CZECHACH}

Niniejszy artykuł analizuje znaczenie dobrowolnych działań środowiskowych dla funkcjonowania firmy. W ostatnich dziesięcioleciach pojawiło się wiele trendów, które podwyższają znaczenie przyjaznego podejścia do środowiska naturalnego z perspektywy udanych działań przedsiębiorstw. Określony poziom ochrony środowiska naturalnego jest wyznaczany za pośrednictwem wymogów prawnych danego kraju. Obecnie przedsiębiorstwa mogą w tej dziedzinie rozwijać inne działania wychodzące ponad poziom 
wymogów obowiązkowych. Celem artykułu jest dokonanie przeglądu podstawowych dobrowolnych instrumentów w zakresie poszanowania środowiska naturalnego, a w przypadku wybranych instrumentów opis ich wykorzystania w Republice Czeskiej. Kolejnym celem jest zwięzłe przedstawienie opinii mieszkańców Republiki Czeskiej na temat stanu i ochrony środowiska w Republice Czeskiej. Przedsiębiorstwa mogą korzystać z kilku dobrowolnych instrumentów. Za główne dobrowolne instrumenty są uważane: EMAS i oznakowanie ekologiczne. Za potencjalne korzyści obu typów narzędzi wskazuje się możliwe oszczędności oraz zwiększenie przychodów.W Czechach wykorzystywane są oba typy dobrowolnych instrumentów. Ich zastosowanie nie jest jednak zbyt powszechne. W Czechach przyznano mniej niż 100 licencji „produkt przyjazny dla środowiska” a certyfikację EMAS posiada mniej niż 30 organizacji. Badania dotyczące wpływu dobrowolnych instrumentów środowiskowych na efektywność przedsiębiorstw pokazują, że ich wydajność środowiskowa się zazwyczaj podwyższa, choć nie jest zawsze osiągana. Badania przeprowadzone wśród czeskich konsumentów pokazują, że są oni raczej zadowoleni ze stanu środowiska naturalnego. Większość mieszkańców zgadza się $\mathrm{z}$ działaniami i inwestycjami mającymi na celu ochronę środowiska naturalnego. $\mathrm{Z}$ owych badań można również wnioskować, że na terenie Czech istnieje potencjalny popyt na produkty przyjazne środowisku.

Słowa kluczowe: strategie zarządzania środowiskowego, oznakowanie ekologiczne, EMAS, dobrowolne instrumenty.

DOI: $10.7862 /$ rz.2016.mmr.48

Tekst złożono w redakcji: listopad 2016

Przyjęto do druku: grudzień 2016 